\title{
Impact of Performance Appraisal on Employee Performance: A Critical Case Study of Sui Southern Gas Company Limited
}

\author{
Sabera Suleman*and Dr. Farooq-e-Azam Cheema \\ audacious_lass@hotmail.com \\ SZABIST \\ Karachi, Pakistan
}

\begin{abstract}
Today, almost in all large/medium-sized organizations, performance appraisal is adopted in one form or the other for administrative purposes, retention/layoff decisions, as well as for developmental purposes. Keeping in view wide-scale efficacy of the performance appraisal as a management tool, the researcher chose Sui Southern Gas Company (SSGC), a public sector autonomous body to study its practical implications. The researcher wanted to determine whether the appraisal program used in the company is merely a useless bureaucratic attempt as part of the company's requirement. Further, if the company constructively employs appraisal system then this paper addressed the various facets of the performance appraisal exercise and the effect these aspects have on the performance of employees working at SSGC. In-depth interviews and questionnaires were used as main sources of collecting the primary data from the employees of SSGC and the sampling method chosen by the researcher was Stratified Sampling. This study successfully reached the conclusion that although the organization formally focuses on the performance appraisal process, it has not been able to utilize it owing to ineffective evaluation techniques used and a wide communication gap between the managers and the employees in terms of performance management.
\end{abstract}

Keywords: Performance appraisal, performance evaluation, performance assessment, performance planning, feedback, coaching

\section{INTRODUCTION}

Performance Appraisal, a two-worded organizational management term necessarily stimulates strong feelings, views, and responses amid employer-employee relationship in the organizational setting aimed at managing performance level of the former by the latter. A generation ago, appraisal systems tended to emphasize employee traits, deficiencies and abilities, but modern appraisal philosophy focuses on present performance and future goals [1]. Modern philosophy also stresses on performance appraisal being effectively used to create a learning environment that motivates the employees to develop themselves and improve their performance. However, it has also been deemed to be one of the most Journal of Independent Studies and Research (JISR) - Ma problematic components of human resource management and is viewed as either a futile bureaucratic exercise or worse, a destructive influence on the employee-supervisor relationship [2]. of:

Thus, this study intends upon determining the impact

1. Objectives of performance appraisal

2. Factors considered while planning the performance

3. Procedures of performance appraisal used

4. The level of feedback provided after the performance evaluation; on the performance of employees at SSGC

In other words, the study aims to sketch out the level and extent to which the performance appraisal system is adopted by SSGC and to find out the implications of the strengths and weaknesses of the system on the performance of the employees of the organization.

\section{RESEARCH METHODOLOGY}

This research was based on Case Study Strategy supported by Survey Strategy. SSGC was taken as a case to test the theory of effectiveness of performance appraisal in the organization. In-depth interviews and questionnaires were used as main sources of collecting the primary data. Primary empirical data were supported by the secondary data comprising three comprehensive reference cases that boosted the researcher's insight over the issue and helped conduct a far-reaching analysis and debate. The sampling method, which was chosen by the researcher, was Stratified Sampling. As stratified sampling involves dividing the population into homogenous groups, the researcher based the strata on positions along hierarchy.

The researcher selected four strata: top management, middle management, lower level management and nonmanagers.

Total sample size determined by the research was 70 employees, managerial and non-managerial employees in equal proportion, from the departments of HR, gement and Social Sciences \& Economics 
Administration and Services, Material Management, Information Technology and Finance. In-depth interviews were conducted with five interviewees. Their distribution was two non-managers, one lower level manager, one middle level manager and one higher-level manager.

\section{LITERATURE REVIEW}

\subsection{What is Performance Appraisal?}

In the organizational context, performance appraisal is defined as "the process of identifying, evaluating and developing the work performance of the employee in the organization, so that organizational goals and objectives are effectively achieved while, at the same time, benefiting employees in terms of recognition, receiving feedback, and offering career guidance" [3]. The terms 'performance assessment', 'performance evaluation', and most recently 'performance management' are also used to describe the process.

\subsection{Objectives of Performance Appraisal}

According to researchers, performance appraisal is used as a management tool i.e. having the ability to increase the performance of employees and the effectiveness of the organization [4], [5]. The purpose of performance appraisal is also identified as to control an individual's behavior to the manager's satisfaction [5]. Katsanis et al [5] described the purpose of an effective performance appraisal as an encouragement to individual performance while reinforcing organizational objectives. However, according to Bell [6], the objective of the appraisal is not an opportunity to criticize any individual's personality or opinions, or other colleagues.

\subsection{Models and Techniques of Performance Appraisal}

\section{0-Degree Performance Appraisal}

360-appraisal process involves multiple sources of feedback to appraise, not only the employee but the manager as well [7]. Multisource feedback system enriches the performance appraisal process by adding perspectives of direct reports, colleagues, and sometimes customers [7]. Tomow [8] purports that the 360-degree feedback serves as a key relationship-building tool that organizations can use to enhance team processes and work interrelationships. Bemardin [9] supports this view by stating that when implemented properly, subordinate appraisal systems enhance worker job satisfaction and morale.

\section{Forced Distribution Rating Method}

Forced distribution ratings follow a bell curve, placing smaller percentages of workers at the highest and lowest performance levels and the bulk of employees somewhere in the middle [10]. Aspects of the systems that may be problematic include the potential for adverse impact against older workers, inconsistency with previous performance reviews, poor management communication about program administration, subjectivity of the criteria used in reduction-in-force decisions and the potential for disregarding existing policies when making reduction-inforce decisions [10].

\section{Critical Incident Technique}

The term is used to describe a method of performance appraisal that made lists of statements of very effective and very ineffective behavior for employees [11]. The lists have been combined into categories, which vary with the job. Once the categories had been developed and statements of effective and ineffective behavior had been provided, the evaluator prepared a log for each employee. During the evaluation period, the evaluator recorded examples of critical behaviors in each of the categories, and the log has been used to evaluate the employee at the end of the evaluation period [11].

\subsection{Providing Feedback on Employee Performance}

Research [12], [13] demonstrated that clear, specific, and descriptive feedback, compared to evaluative outcome feedback, resulted in more accurate evaluations of expectancy for success, led to perceptions of source credibility and fairness, and increased performance by allowing for accurate attributions about past performance. A feedback meeting can serve as an important role in exploring and promoting employees' career development opportunities as well as their contributions to organizational change efforts [13].

\section{INTEGRATION AND ANALYSIS OF DATA}

\subsection{Planning the Employee's Performance Goals and Standards}

$81 \%$ of managers, $71 \%$ non-managers from the questionnaire data and all the five interviewees believe that the planning of an employee's performance is based on the goals, objectives and key responsibilities of an employee's job at SSGC. Data from questionnaire reflects that $63 \%$ of the managers, $48 \%$ of the non-managers and all the five interviewees asserted to the point that the

Journal of Independent Studies and Research (JISR) - Management and Social Sciences \& Economics Volume 6, Number 2, July 2008 
employees are allowed to participate in setting the goals and objectives of their performance at SSGC. However, questionnaire data shows that about $52 \%$ of the nonmanagers were of the view that the managers did not have any formal discussion with them with respect to the planning of their performance. On the other hand, the questionnaire data shows that 55\% managers agreed that they directly interact with the employees to carry out their performance planning. Only interviewees 3 and 5 stated that the managers have a thorough discussion with the employees about their performance plan. This not only reflects conflict of opinion between managers and nonmanagers, but also that the performance planning discussion depends upon managers to managers, as it does not happen in every case.

\subsection{The Objectives of Performance Appraisal in SSGC}

Interviewee 5, GM HR, identified three objectives of performance appraisal in SSGC: achievement of the corporate goal, measurement of employee contribution towards those goals and development of employees.

As a vast majority of managers (81\%) and nonmanagers $(71 \%)$, from the questionnaire data and all five interviewees indicate that one of the purposes of performance appraisal at SSGC is indeed administrative one. Formal appraisals are certainly required in an organization to justify a wide range of human resource decisions such as pay raises, promotions, demotions, terminations, etc. [14]. Although $61 \%$ of the respondents from the questionnaire data believe that performance appraisal is used for strategic reason, only one interviewee, who happens to be in the top management, believes that performance appraisal in SSGC is in line with the company's vision, mission and goals. The data obtained from questionnaires and interviews do not, correspond, due to which the researcher cannot correctly infer the true nature of strategic performance appraisal utilized in the organization.

However, $71 \%$ of the managers and $57 \%$ of the nonmanagers at the SSGC mutually agree that performance appraisal is employed in SSGC to identify the developmental needs of the employees. Interviewees 2, 3 and 5 are of the same view as well. Interviewee 5 further explained that career planning of each employee takes place in the company to determine his/her career progress. To emphasize the necessity of employee development, McGregor [15] argued that one of the objectives of performance appraisal was to create a learning experience that motivates staff to develop themselves and improve their performance. Thus, the empirical data suggests that the employees at SSGC receive required skill developmental aid in the form of training, career planning and attainment of developmental goals.

\subsection{The Procedures and Techniques of Performance Appraisal Used in SSGC}

The technique of performance appraisal used in SSGC is forced ranking system (interviewee 1 and 5). However, previous studies [10], [16] show that forced ranking system is not an effective tool for evaluating performance of employees.

Majority of the non-managers (48\%) believed that there is no formal appraisal interview between the manager and the employee, whereas, 56\% of the managers agreed that appraisal interviews are conducted between the employees and the managers. Interestingly, none of the interviewees asserted to this point. Therefore, the discrepancy in the viewpoints of managers and nonmanagers suggest that the managers want to come clean and appear that they have been evaluating their subordinates fairly, which as the opinions of nonmanagers and interviewees show is not entirely true. However, it is of utmost importance to provide undivided attention during the interview and reserve adequate time for a full discussion of the issues [17]. 360-degree feedback appraisal method is not used by the organization as all the interviewees and $66 \%$ of the respondents from the questionnaire data disagree that the opinion of colleagues. However, 360-degree feedback can have enormous power, perhaps, more than any other technique to bring an individual's shortcomings to his attentions and confirm that areas of perceived strengths are actual and recognized strengths [18].

\subsection{Importance of Feedback and Coaching After Performance Evaluation}

In a performance management system, feedback plays an important role both for motivational and informational purposes and for improved rater-ratee communications [19]. However, the concept of feedback system in SSGC does not tally with these studies. Most of the managers (62\%) acknowledged themselves as providing proper appraisal feedback to their subordinates. On the contrary, more than half of the non-managers (55\%) disagreed with the managers. This, once again, reflects divergence of opinion between the managers and non-managers. Managerial level employees appear either satisfied with the way they provide feedback to their employees or are not reporting the real scenario as once more nonmanagerial employees are not satisfied with the level of communication taking place between them.

Journal of Independent Studies and Research (JISR) - Management and Social Sciences \& Economics Volume 6, Number 2, July 2008 
Coaching and mentoring is essential within the workplace and must take into the consideration the human factor and characteristics [15]. More than 50\% of the nonmanagerial employees claimed to get no coaching and support from their managers if such a need arises as per their appraisal outcome. On the contrary, $56 \%$ of the managers conversely think that they do help and offer guidance to their subordinates. The variation in viewpoints again implies that higher-level employees do not give a very true picture of the situation as lower level employees do not support their beliefs and are not pleased with their manager when it comes to communication and interaction between them.

\section{CONCLUSION AND RECOMMENDATIONS}

\subsection{Conclusion}

Although the performance planning section of SSGC's performance management system considers developmental factors as well as sets standards on the basis of the behavior and competencies of the employees, the system is not effective when it comes to its implementation. Following are the reasons why:

- There is no formal dialogue session between the employees and managers during the performanceplanning phase as per the non-managers. This suggests the beaureaucratic and hierarchical differences between the higher level and lower level employees, resulting in lack of communication between them.

- The company's use of only one technique, which is forced ranking system, is not leading to a positive impact on the performance of employees. The employees are not satisfied with this performance appraisal method. Moreover, 360degree feedback method, which is considered a powerful technique more than others [18], is not employed by the organization.

- Once again, the communication gap between managers and non-managers is reflected as the findings show that the non-managers are of the view that the assessment only involves ratings given by the managers. That is, there is no formal appraisal interview between the managers and performance appraisal system [17].

- $\quad$ After the appraisal the non-managers believe that the employees are not provided with sufficient feedback, whereas, the managers stated the otherwise. The divergence of opinion once more implies that the level of interaction and communication is low, even though it is very essential for the managers to communicate the employees, which is an essential part of the

strengths and weaknesses to their subordinates in order to bring forth improvement in their performance [20].

- Lastly, the findings show that managers are pleased with the performance aid they provide to their employees, however, the study show that the non-managers do not hold the same opinion. Thus, the researcher concludes that the managers are not bothered to find out whether the employees require their assistance and hence, are not providing sufficient support to their subordinates for the improvement of their performance.

\subsection{Recommendations}

- $\quad$ For performance appraisal to play a positive role in employee's performance, it is essential for the managers to personally sit down with the employees to discuss their objectives, responsibilities, competencies and skills that their jobs require.

- The company should consider revising or eliminating the current forced distribution technique being used for appraising performance. Instead, SSGC should employ 360-degree feedback method in order to have a more effective evaluation of their employees' performances.

- There should be a formal appraisal interview and feedback session between the employees and the managers. Only after discussing the problem, areas of the performance the employee would be able to improve upon those areas [21]. Additionally, if the employees require any assistance and coaching, the managers should be more than ready to provide it as support focuses on motivating employees on performance [21].

\section{REERENCES}

[1] J. W. Newstrom, \& K. Davis, Organizational Behavior: Human Behavior at Work, 9th ed. New York: McGraw-Hill, 1993.

[2] L. M. Coutts, \& F.W. Schneider, "Police officer performance appraisal systems: how good are they?" Policing: An International Journal of Police Strategies \& Management, 27 (1): 67-81, 2004.

[3] R. Lansbury, Human Resource Management, Australia, 1988.

Journal of Independent Studies and Research (JISR) - Management and Social Sciences \& Economics Volume 6, Number 2, July 2008 
[4] C. McNamara, "Complete guide to ethics management: An ethics toolkit for managers," 2005. www.managementhelp.org/ethics/ethxgde.htm Accessed: 08 Nov. 07.

[5] L. P. Katsanis, J. G. Laurin., \& D. A. Pitta, "How should product managers' job performance be evaluated in emerging product management systems?” Journal of Product \& Brand Management, Vol. 5, Issue 6, 5-23, 1996.

[6] L. A. Bell, Management Skills in Primary School, London: Routledge, 1988a.

[7] Richard Lepsinger, and Antoinette D. Lucia, The Art and Science of 360 Feedback. California, US: Pfeiffer Imp of Jossey-Bass Publishers, 1997.

[8] Walter M. Tornow, "Forces That Affect the 360Degree Feedback Process," Maximizing the Value of 360-Degree Feedback, San Francisco: Jossey-Bass Publishers, 1998.

[9] H. J. Bernardin, R. W. Beatty, Performance Appraisal: Assessing Human Behavior at work, Boston, MA: Kent Publishing Co., 1986.

[10]R. J. Nobile, “...More on 'Forced Ranking,” $H R$ Advisor, West Group, January/February, pp. 46-49, 2004.

[11]William F. Glueck, A Diagnostic Approach, 3rd ed. Plano, Texas, Business Publications, 1982.

[12] P. Bobko, \& A. Colella, "Employee reactions to performance standards: A review and research propositions," Personnel Psychology, 47(1):1-29, 1994.

[13] M. London, H. H. Larsen, \& L. N. Thisted, "Relationships between feedback and selfdevelopment,” Group \& Organization Management, 24 (1), 5-27, 1999.

[14] C. O., Longenecker and L.S. Fink, "Creative Effective Performance Appraisals,” Industrial Management, 1823, 1999.

[15]D. McGregor, The human side of enterprise, Middlesex: Penguin Books, 1987.

[16] A. R. McIlvaine, "Study Examines Rank and Yank," Human Resource Executive, May 16, p. 10, 2005.

[17]G. E. Roberts, "Maximizing Performance Appraisal System Acceptances, Perspectives from Municipal

Journal of Independent Studies and Research (JISR) - Management and Social Sciences \& Economics Volume 6, Number 2, July 2008
Government Personnel Administrators,” Public Personnel Management, 23: 525-549, 1994.

[18]D. Grote, Forced Ranking: Making Performance Management Work, Massachusetts: Harvard Business School Press, 2005.

[19] P. J. Taylor, \& J. L. Pierce, "Effects of introducing a performance management system on employees' subsequent attitudes and effort," Public Personnel Management, 28 (3), 423-452, 1999.

[20]M. J. Camardella, "Effective Management of the Performance Appraisal Process,” Employment Relations Today, 30 (1):103-107, 2003.

[21] N. M. Somerick, "Strategies for Improving Employee Relations by Using Performance Appraisals More Effectively,” Public Relations Quarterly, 38 (3), 3739, 1993. 